Vol. 54, Issue 5, 581-594, 2021

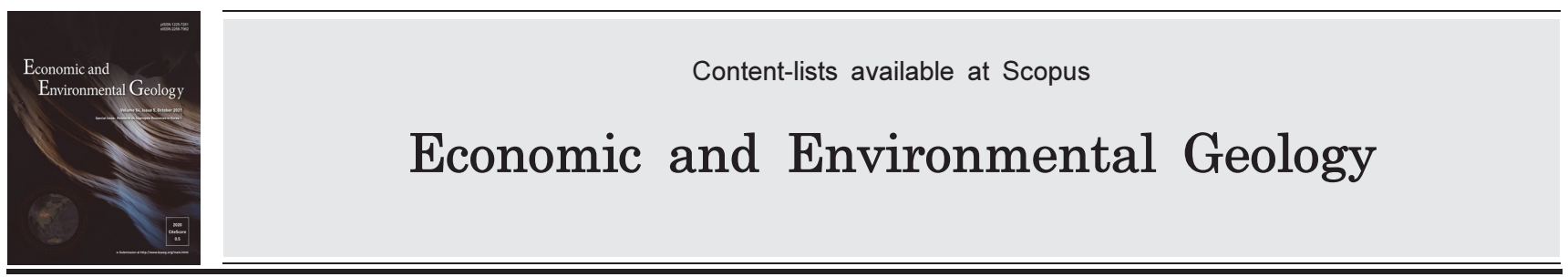

Research Paper

\title{
Aggregate of Korea in 2020
}

\author{
Sei Sun Hong, Jin Young Lee \\ Geologic Research Center, Korea Institute of Geoscience and Mineral Resources, Daejeon 34132, Korea
}

*Corresponding author : jylee@kigam.re.kr

\section{ARTICLE INFORMATION}

Manuscript received 9 October 2021

Received in revised form 23 October 2021

Manuscript accepted 24 October 2021

Available online 29 October 2021

DOI : http://dx.doi.org/10.9719/EEG.2021.54.5.581

\section{Research Highlights}

- A total of 131 million $\mathrm{m}^{3}$ of aggregate was produced for consumption in the Republic of Korea in 2020.

- In 2020, a total of 148 local governments produced aggregate from 889 active operations.

- The leading producing local governments in 2020 were, in descending order of volume, Hwaseoung-si, Ongjin-gun, Paju-si, Cheongju-si, Pocheon-si, Yongin-si.

- The combined production of the top 38 local governments was about 85 million $\mathrm{m}^{3}$, which means that about $17 \%$ of the local governments produced $65 \%$ of the total production in 2020 .

\begin{abstract}
In 2020, about 132 million $\mathrm{m}^{3}$ of aggregate was produced in Korea. Of the total domestic aggregates produced in 2020, about $33.3 \%$ was sand and about $66.7 \%$ was gravel. It estimated that of the 132 million $\mathrm{m}^{3}$ of aggregates in Korea in 2020 , about $52 \%$ was produced by screening crushed aggregate, by $36 \%$ by forest aggregate, $3 \%$ by land aggregate, $5.6 \%$ by sea aggregate and $2.5 \%$ by washing each other, and $0.4 \%$ by river aggregate. This indicates that screening crushed aggregate and forest aggregate are the main producers of domestic aggregates. Leading producing metropolitan cities were Gyeonggi-do, Gyeongsangnam-do, Chungcheongbukdo, Gangwon-do, Chungcheongnam-do, Incheon in order decreasing volume, which together accounted for about $72.4 \%$ of total product. In 2020, aggregates were produced in 153 cities, about $67 \%$ of the 231 cities of Korea, 38 local governments have developed aggregates of more than 1 million $\mathrm{m}^{3}$, and the combined production of the 38 cities accounted for about $65 \%$ of national total. This means that the aggregate extraction trend of local governments is becoming larger and more concentrated. In 2020 , at 153 local governments, a total of 889 operations produced aggregates with 420 operations by permission, 469 operations by declaration. A review of production by size of operation indicated that about 17 million $\mathrm{m}^{3}(12.8 \%$ of the total aggregate) was produced by 14 operations reporting production of more than 1 million $\mathrm{m}^{3}$. In about 420 operations, the maximum period of permit is 32 years to at least 2 months. When the remaining period of permit is taken into account, only about $55 \%$ of active operations can be developed the aggregate after 2021. In order to maintain the permitted aggregate volume by 2020 level, it will be necessary to obtain an extension permit or find new operation sites for at least 200 or more operations.
\end{abstract}

Keywords : aggregate, sand, gravel, aggregate source, local government

Citation: Hong, S.S., Lee, J.Y. (2021) Aggregate of Korea in 2020. Korea Economic and Environmental Geology, v.54, p.581-594, doi:10.9719/EEG2021.54.5.581.

This is an Open Access article distributed under the terms of the Creative Commons Attribution Non-Commercial License (http://creativecommons.org/ licenses/by-nc/3.0) which permits unrestricted non-commercial use, distribution, and reproduction in any medium, provided original work is properly cited. pISSN 1225-7281; eISSN 2288-7962/@2021 The KSEEG. Printed by Hanrimwon Publishing Company. All rights reserved. 


\section{연구논문}

\section{0년도 국내 골재 수급 분석}

홍세선 · 이진영*

한국지질자원연구원 지질연구센터

*책임저자 : jylee@kigam.re.kr

\section{요 약}

2020년에 국내 골재 총 채취량은 약 1 억 3,150 만 $\mathrm{m}^{3}$ 이며, 이 중 모래는 약 4,386 만 $\mathrm{m}^{3}(33.3 \%)$, 자갈은 약 8,749 만 $\mathrm{m}^{3}(66.7 \%)$ 채 취되었으며, 허가채취는 약 5,858 만 $\mathrm{m}^{3}(45 \%)$, 신고채취는 약 7,277 만 $\mathrm{m}^{3}(55 \%)$ 이다. 골재원별로 보면 하천골재 약 50 만 $\mathrm{m}^{3}$, 육상 골재 약 380 만 $\mathrm{m}^{3}$, 산림골재 약 4,680 만 $\mathrm{m}^{3}$, 바다골재 약 740 만 $\mathrm{m}^{3}$, 선별파쇄 약 6,827 만 $\mathrm{m}^{3}$, 선별세척 약 331 만 $\mathrm{m}^{3}$, 그리고 기타신 고골재가 약 110 만 $\mathrm{m}^{3}$ 로 선별파쇄골재와 산림골재가 전체 채취량의 약 $88 \%$ 차지하고 있다. 경기도가 광역시도에서는 골재를 가장 많이 채취하였으며, 그 다음으로 경상남도, 충청북도, 강원도 충청남도, 인천광역시의 순이다. 2020 년에는 231 개 시군구의 약 $67 \%$ 인 153 개 시군구에서 골재를 채취하였으며, 38 개 시군구에서 100 만 $\mathrm{m}^{3}$ 이상의 골재를 채취하였으며, 채취량은 전국 채 취량의 $65 \%$ 인 약 8,567 만 $\mathrm{m}^{3}$ 이다. 2020 년도에는 약 1040 여개소의 채취장이 운영되었으나 실제 골재를 채취한 채취장은 약 889 개 채취장으로 선별파쇄장이 약 415 개소로 가장 많으며, 산림골재, 육상골재장은 200 개소 내외이다. 100 만 $\mathrm{m}^{3}$ 이상을 채취한 채 취장은 14 개 채취장이며, 1 만 $\mathrm{m}^{3}$ 이하의 소규모 채취장도 약 126 개소이다. 약 420 여개의 허가채취장에서 허가기간은 최장 32 년 에서 최소 2 개월이며, 허가 잔여기간을 보면 2021년 이후 채취가능한 채취장이 약 $55 \%$ 이며, 2020년 수준의 허가 골재채취물량 을 유지하기 위해서는 최소한 200여개 이상의 채취장에 대해 허가연장, 신규허가가 필요할 것이다.

주요어 : 2019년 골재채취실적, 산림골재, 선별파쇄골재, 육상골재, 하천골재

\section{1. 서 론}

1991년 골재채취법이 제정된 이후 국토교통부는 1992 년부터 골재채취통계 집계하여 골재자원정보관리시스템 (www.agris.go.kr)에서 그 현황을 관리하고 있다. 1992년 부터 2020년 까지 채취된 골재 물량은 약 38.8 억 $\mathrm{m}^{3}$ 로, 매년 채취량의 변동은 있지만 연평균 약 1 억 3,000 만 $\mathrm{m}^{3}$ 내외의 골재를 채취하여 국토건설산업의 필수적인 재료 로 공급하고 있다. 국토교통부는 매년 골재수급계획, 5년 마다 5개년 골재수급기본계획(MLIT, 2014, 2018)을 수립 하여 골재자원의 안정적이고, 지속적인 공급을 위해 노 력하고 있다. 또한 골재자원정보관리시스템을 활용하여 매년 분기별로 각 지자체에서 골재 채취현황을 집계하여 관리하고 있다. 그러나 아직까지는 매년 채취되는 골재 의 시군구별 현황 및 채취장별 현황분석 및 이들이 어떠 한 특성을 보이며, 지역별 채취특성, 어떤 골재원이 우세 하게 채취되며, 그 물량은 어느 정도인지 등에 대한 채 취현황분석은 자세하게 보고된 바 없다. 따라서 이 연구 에서는 2020년도에 집계된 전국 골재채취현황을 분석하 여 광역시도별, 시군구별, 채취장별 골재채취특성을 분석 하여 향후 골재수급에 도움이 될 수 있는 기초자료를 제
공하고자 한다.

골재채취에 대한 현황은 세계의 대부분의 국가에서, 노 르웨이 지질조사소(Geological survey of Norway), 스웨 덴지질조사소(Geological Survey of Sweden), 미국 지질 조사소(U.S.Geological Survey), 영국 지질조사소(British Geological Survey) 등과 같은 지질관련 국가기관에서 관 리한다. 특히, 미국의 예를 보면 sand and gravel(하천, 육 상, 바다골재)과 stone, crushed(산림, 선별파쇄)로 구분하 여 골재 채취량, 업체, 채취장, 암종별, 용도별로 매년 채 취현황을 분석하고 있다(Willett, 2020(a), 2020(b)). 국내 에서는 간헐적으로 최근에 골재채취현황에 대한 수급분 석에 대한 연구가 이루어지고 있다(Hong, et al., 2015, 2020, 2021(a), (b)).

\section{2. 연구방법}

이 연구에서는 광역시도, 시군구, 채취장별로 구분하여 골재채취현황을 분석하였다. 분석대상 광역시도는 서울 등 17 개 광역시도, 시군구는 광역시의 구군을 포함한, 서 해 및 남해EEZ 포함 231개 시군구, 그리고 2020년도에 채취현황의 채취장수를 파악하여 분석의 기초통계자료로 
사용하였다. 채취장의 기준은 2020년에 허가기간은 남아 있으나 채취량이 없거나 이미 허가물량을 소진하여 채취 량이 없는 채취장은 제외하였으며, 연장허가나 신규허가 에 의해 동일한 채취장이기는 하지만 별도의 채취실적을 보고하는 경우는 서로 다른 채취장으로 간주하였다. 또 한 동일 업체이지만 골재원이 다르거나 채취장소가 다른 경우는 별도의 채취장으로 간주하였으며, 바다골재의 경 우 채취지역은 같은 장소이지만 채취업체가 다른 경우 서로 다른 채취장으로 간주하였다. 즉, 채취실적이 별도 로 기록되는 경우는 모두 별도의 채취장으로 간주하였다. 따라서 국토교통부에서 집계된 골재채취현황과는 물량, 채취장 수 등은 약간 상이할 수 있다.

\section{3. 전국채취현황}

2020년도에는 국내에서 약 1 억 3,135 만 $\mathrm{m}^{3}$ 의 골재가 채취(Table 1)되었으며, 이는 2019년도의 1억3,400만 $\mathrm{m}^{3}$ 보다는 약간 적다. 2020년 채취물량 중에서 모래는 약 4,386 만 $\mathrm{m}^{3}(33.3 \%)$, 자갈은 약 8,749 만 $\mathrm{m}^{3}(66.7 \%)$ 가 채취 되어 모래보다는 자갈이 월등히 많이 생산되었다(Table 1 , Fig. 1). 일반적으로 국내 골재의 약 $73 \%$ 를 사용하는 레미 콘에서는 모래의 자갈의 비율이 약 5.2:4.8로 모래와 자갈
의 사용량은 거의 비슷하다. 따라서 모래와 자갈의 서로 비슷한 비율로 채취되는 것이 가장 이상적인데 2020년에 는 모래의 생산비율이 자갈보다 적다. 국내에서 골재를 채취하고자 하면 골재채취허가를 득하는 방법과 비허가 신고에 의해 골재를 생산하는 방법이 있다. 2020년도에 는 골재허가에 의한 채취와 신고에 의한 채취 점유비가 약 45:55의 비율로 신고에 의한 골재 생산이 많다(Fig. 1). 또한 Table 1와 Fig. 2에서 보는 바와 같이 골재원별로 보면 하천골재 약 50 만 $\mathrm{m}^{3}$ (총채취량의 약 $0.2 \%$ ), 육상골재 약 380 만 $\mathrm{m}^{3}$ (총채취량의 $2.9 \%$ ), 산림골재 약 4,680 만 $\mathrm{m}^{3}$ (총
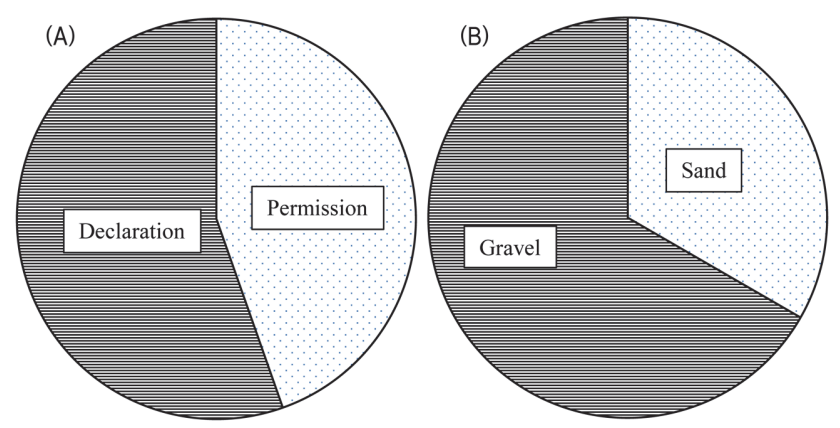

Fig. 1. The aggregate production in Korea. (A) production rate of permission and declaration, (B) sand and gravel.

Table 1. The aggregate production in Korea in 2020, by provinces, by aggregate sources (unit : ten thousand $\mathrm{m}^{3}$ )

\begin{tabular}{|c|c|c|c|c|c|c|c|c|c|c|c|}
\hline & \multicolumn{4}{|c|}{ permission } & \multicolumn{6}{|c|}{ declaration } & \multirow{2}{*}{ total } \\
\hline & river & land & forest & marine & river & land & forest & marine & crushed & washing & \\
\hline Seoul & 0.0 & 0.0 & 0.0 & 0.0 & 0.0 & 0.0 & 0.0 & 0.0 & 0.0 & 0.0 & 0.0 \\
\hline Incheon & 0.0 & 0.0 & 678.0 & $6,012.0$ & 0.0 & 0.0 & 0.0 & 0.0 & $3,414.2$ & 507.0 & $10,611.2$ \\
\hline Gyeonggi-do & 0.0 & 0.0 & $4,840.9$ & 0.0 & 0.0 & 0.0 & 0.0 & 0.0 & $33,351.9$ & 484.3 & $38,677.1$ \\
\hline Gangwon-do & 31.0 & $1,239.4$ & $6,080.4$ & 0.0 & 0.0 & 0.0 & 57.0 & 0.0 & $4,048.5$ & 0.0 & $11,456.3$ \\
\hline Chungcheongbuk-do & 0.0 & 318.3 & $5,623.9$ & 0.0 & 0.0 & 8.0 & 161.0 & 0.0 & $5,567.9$ & 0.0 & $11,679.1$ \\
\hline Daejeon & 0.0 & 0.0 & 0.0 & 0.0 & 0.0 & 0.0 & 0.0 & 0.0 & 29.0 & 0.0 & 29.0 \\
\hline Sejong & 0.0 & 0.0 & 241.0 & 0.0 & 0.0 & 0.0 & 0.0 & 0.0 & $1,307.6$ & 0.0 & $1,548.6$ \\
\hline Chungcheongnam-do & 0.0 & 220.9 & $5,645.4$ & 106.0 & 0.0 & 0.0 & 0.0 & 0.0 & $4,177.4$ & 528.0 & $10,677.7$ \\
\hline Jeollabuk-do & 0.0 & 677.5 & $4,592.4$ & 0.0 & 0.0 & 0.0 & 0.0 & 0.0 & $1,750.9$ & 0.0 & $7,020.8$ \\
\hline Gwangju & 0.0 & 0.0 & 0.0 & 0.0 & 0.0 & 0.0 & 0.0 & 0.0 & 0.0 & 0.0 & 0.0 \\
\hline Jeollanam-do & 0.0 & 316.9 & $5,993.8$ & 0.0 & 0.0 & 0.0 & 115.0 & 140.0 & $1,955.9$ & 191.0 & $8,712.6$ \\
\hline Daegu & 0.0 & 0.0 & 0.0 & 0.0 & 0.0 & 0.0 & 0.0 & 0.0 & 336.2 & 0.0 & 336.2 \\
\hline Gyeongsangbuk-do & 356.0 & 937.5 & $4,024.2$ & 0.0 & 0.0 & 0.0 & 0.0 & 0.0 & $2,440.9$ & 0.0 & $7,758.6$ \\
\hline Busan & 0.0 & 0.0 & 0.0 & 0.0 & 0.0 & 0.0 & 0.0 & 0.0 & $4,905.7$ & 616.0 & $5,521.7$ \\
\hline Ulsan & 0.0 & 0.0 & $1,433.6$ & 0.0 & 0.0 & 0.0 & 350.1 & 0.0 & 566.7 & 177.7 & $2,528.1$ \\
\hline Gyeongsangnam-do & 111.0 & 14.6 & $6,884.9$ & 0.0 & 0.0 & 0.0 & 0.0 & 267.2 & $4,090.4$ & 648.4 & $12,016.5$ \\
\hline Jeju-do & 0.0 & 131.3 & 777.0 & 0.0 & 0.0 & 0.0 & 0.0 & 0.0 & 428.9 & 142.3 & $1,479.5$ \\
\hline EEZ & 0.0 & 0.0 & 0.0 & $1,294.0$ & 0.0 & 0.0 & 0.0 & 0.0 & 0.0 & 0.0 & $1,294.0$ \\
\hline total & 498.0 & $3,856.4$ & $46,815.5$ & $7,412.0$ & 0.0 & 8.0 & 683.1 & 407.2 & $68,372.1$ & $3,294.7$ & $131,347.0$ \\
\hline
\end{tabular}




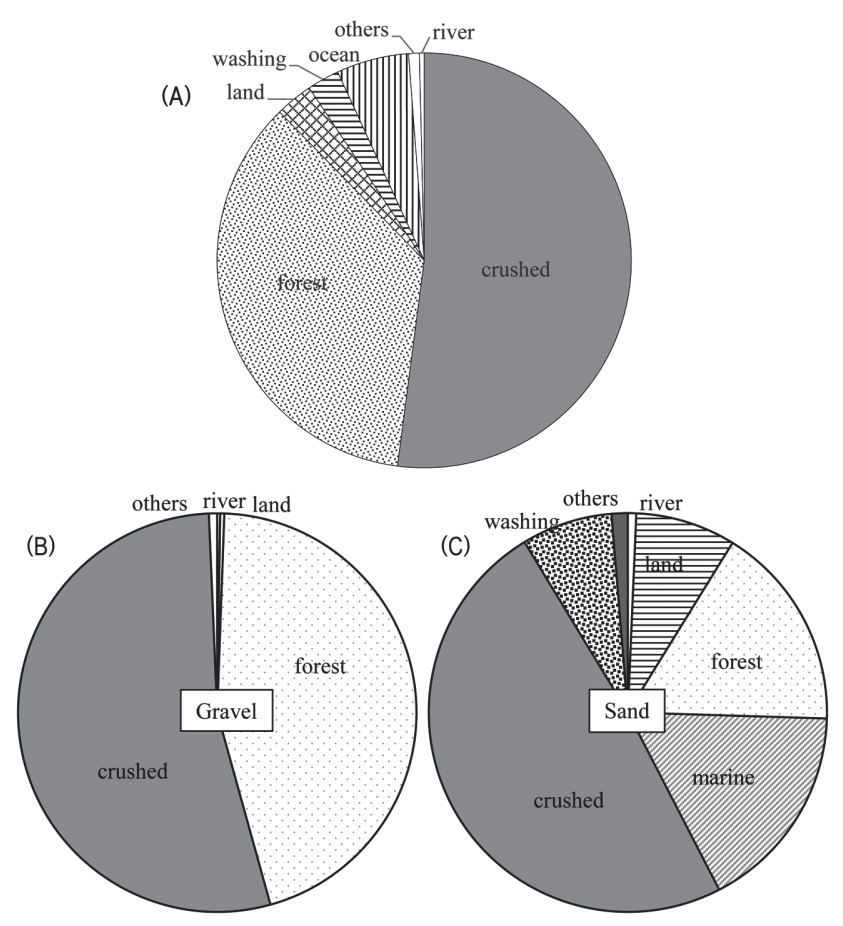

Fig. 2. The aggregate production in Korea, by type and source of aggregate. (A) by sources, (B) production rate of gravel by sources, (C) production rate of sand by sources.

채취량의 $35.6 \%$ ), 바다골재 약 740 만 $\mathrm{m}^{3}$ (총채취량의 $5.6 \%$ ), 선별파쇄 약 6,827 만 $\mathrm{m}^{3}$ (총채취량의 $52.0 \%$ ), 선별세척 약 331 만 $\mathrm{m}^{3}$ (총채취량의 $2.5 \%$ ), 그리고 기타신고골재가 약 110 만 $\mathrm{m}^{3}$ (총채취량의 $0.8 \%$ )를 생산하였다.

\section{4. 골재원별 채취현황}

하천골재 : 과거에는 골재의 수급에 있어 하천골재가 공급원으로서 중요한 역할을 하였으나 4대강 사업이후 주요 하천의 정비로 인해 하천골재의 채취가 거의 중단 되었다. 현재는 일부 정비가 아직 진행되지 않는 구간이 나 지천에서 극히 일부 정비사업 차원에서 하천골재가 개발되고 있다. 2020년에 하천골재는 총 50 만 $\mathrm{m}^{3}$ 가 채 취되었으며, 강원도, 경상북도, 경상남도의 3 개 도의 4 개 시군, 10 개 채취장에서만 부분적으로 개발되어 기초자치 단체에서의 자체적인 사용에 대처되고 있다. 가장 채취 가 활발한 지역은 평창군이나 채취규모는 적고, 경상남 도의 합천군과 경상북도의 구미시의 채취량이 전체 하천 골재 채취량의 $80 \%$ 를 상회한다.

육상골재 : 육상골재는 약 380 만 $\mathrm{m}^{3}$ 가 채취되었으며, 이 중 모래는 약 350 만 $\mathrm{m}^{3}$, 자갈은 약 30 만 $\mathrm{m}^{3}$ 가 개발되 어 모래의 개발비율이 매우 높은 편이다(Table 1, Fig. 2). 육상골재는 선별파쇄, 산림골재, 바다골재 다음으로 많은
양이다. 육상골재의 전체적인 비중은 약 $2.9 \%$ 로 낮은 편 이지만 육상골재의 부존 특성상 각 시군에서 자체적으로 활용하기에 매우 적합한 자원이다. 육상골재의 부존은 주 로 하천 주변의 경작지에 부존되는 특성을 있고, 대규모 보다는 소규모 개발, 그리고 경작지를 활용하는 특성상 단기간 내에 개발해야 점 등은 경작지의 비율이 높은 시 군에서는 시도해볼 만한 골재자원이다.

2020년에는 광역시와 경기도를 제외한 8 개 도의 41개 시군에서 육상골재가 개발되었다. 강원도가 가장 많이 개 발하였으며, 그 다음으로 경상북도, 전라북도, 충청북도 의 순이며, 시군별로는 고성군(강원)에서 가장 많은 양이 채취되었으며, 그 다음으로 고창군, 충주시, 함평군, 강릉 시, 예천군, 구미시 등의 순이다.

산림골재 : 산림골재는 약 4,680 만 $\mathrm{m}^{3}$ 가 채취되었으며, 이 중 모래는 약 730 만 $\mathrm{m}^{3}$, 자갈은 약 3,950 만 $\mathrm{m}^{3}$ 가 채 취되어 자갈의 채취 비율이 모래 보다 5 배 이상 높다 (Table 1, Fig. 2). 산림골재는 선별파쇄골재 다음으로 채 취량이 많은 편으로 2020 년 골재 총채취물량의 약 $35.6 \%$ 이다.

2020 년에는 12 개 광역시도의 77 개 시군에서 산림골재 가 개발되었다. 산림골재는 경상남도에서 가장 많이 채 취되었으며, 강원도, 전라남도, 충청남도, 충청북도의 순 으로 감소한다. 시군별로는 김해시에서 가장 많은 양이 채취되었으며, 그 다음으로 원주시, 파주시, 공주시, 연천 군, 청주시의 순이다.

바다골재 : 바다골재는 약 740 만 $\mathrm{m}^{3}$ 가 채취되었는데 전량 모래이며, 자갈의 채취는 전혀 없다(Table 1, Fig. 2). 바다골재는 골재부존 특성상 주로 서해와 남해에 분포하 는데 2020년에는 인천광역시 옹진군, 충청남도 태안군, 그리고 서해와 남해의 EEZ에서만 바다골재가 채취되었다.

선별파쇄골재 : 선별파쇄골재는 약 6,827 만 $\mathrm{m}^{3}$ 가 채취 되었는데 이는 2020년에 채취된 골재원들 중에서 가장 많은 물량이다. 그리고 매년 선별파쇄골재의 채취량은 소 량이나마 꾸준히 증가하고 있다. 모래는 약 2,139 만 $\mathrm{m}^{3}$, 자갈은 약 4,688 만 $\mathrm{m}^{3}$ 가 생산되었으며, 모래보다는 자갈 의 생산이 2 배 이상 높다(Table 1, Fig. 2). 선별파쇄골재 는 골재의 개발실적이 전혀 없는 서울과 광주를 제외한 모든 광역시도에서 생산되어 골재원들 중 가장 저변이 넓은 편이다. 선별파쇄골재는 경기도에서 압도적으로 많 이 생산되었는데 선별파쇄골재 총생산량의 약 $50 \%$ 가까 이를 점유한다. 그 다음으로는 충청북도, 부산광역시, 충 청남도, 경상남도의 순이며, 전라남북도는 비교적 선별파 쇄골재의 생산이 적은 편이다. 시군구에서는 화성시가 약 660 만 $\mathrm{m}^{3}$ 로 가장 많은 생산량을 보이며, 그 다음으로 용 인시, 광주시, 포천시, 부산강서구, 파주시 등의 순이다. 
선별세척골재 : 선별세척골재는 약 337 만 $\mathrm{m}^{3}$ 가 생산되 었으며, 이 중 모래는 331 만 $\mathrm{m}^{3}$, 자갈은 약 7 만 $\mathrm{m}^{3}$ 로 모 래의 비율이 $90 \%$ 이상이다(Table 1, Fig. 2). 선별세척골 재는 주로 바다를 접하고 있는 광역시도에서 주로 생산 되며, 경상남도, 부산, 인천, 경기도, 충청남도 등에서 생 산된다. 서산시가 약 53 만 $\mathrm{m}^{3}$ 를 생산하여 가장 많은 생 산량을 보이며, 그 다음으로 인천서구, 부산사하구, 창원 시, 평택시, 부산남구의 순이다.

기타 골재 : 기타 골재는 약 110 만 $\mathrm{m}^{3}$ 가 채취되었으며, 모래와 자갈의 비율은 50:50 이다(Table 1, Fig. 2). 대부 분의 신고골재는 선별파쇄골재와 선별세척골재에서 거의 전량 생산되며, 그 외의 신고골재에서는 지역의 개발특 성상 소량이며, 한 두 개의 시군에서 매우 간헐적으로 채 취된다. 2020년에는 육상신고, 산림신고, 바다신고골재가 채취되었으며, 육상골재 1 개시군, 산림골재 4 개 시군, 바 다골재 3 개 시군에서 각각 신고골재가 생산되었다.

\section{5. 광역시도별 골재채취 현황}

전국 17 개 광역시도 중 전년과 마찬가지로 서울특별시 와 광주광역시를 제외한 15 개 광역시도에서 골재개발이 이루어졌다. 광역시도별로 보면 경기도에서 2020년도 골 재채취량의 약 $29.4 \%$ 가 채취되었으며, 그 다음으로 경상 남도(전국 골재채취량 대비 $9.1 \%$ ), 충청북도 $(8.9 \%)$, 강원
도 $(8.7 \%)$, 충청남도 $(8.1 \%)$, 인천광역시 $(8.1 \%)$ 의 순으로 각 각 1,000 만 $\mathrm{m}^{3}$ 이상의 골재를 채취하였다. 전라남도 $(6.6 \%)$, 경상북도 $(5.9 \%)$, 전라북도 $5.3 \%)$, 부산광역시 $(4.2 \%)$ 는 약 500 만 800 만 $\mathrm{m}^{3}$ 의 골재를, 그 밖의 울산광역시 $(1.9 \%)$, 세종시(1.2\%), 제주도(1.1\%), EEZ(1.0\%)에서는 100 만 200 만 $\mathrm{m}^{3}$ 의 골재를 채취하였다. 대구와 대전광역시는 $1 \%$ 미 만의 소규모 채취만 이루어졌다.

수도권 : 서울특별시는 골재의 채취가 전년도와 마찬가 지로 전혀 없으며, 인천광역시와 경기도에서만 골재의 채 취가 이루어졌다. 인천광역시는 약 1,060 만 $\mathrm{m}^{3}$, 경기도는 약 3,870 만 $\mathrm{m}^{3}$ 의 골재를 채취하였다. 모래는 인천광역시 에서 약 700 만 $\mathrm{m}^{3}$, 경기도에서 약 1,330 만 $\mathrm{m}^{3}$, 자갈은 인 천광역시에서 약 360 만 $\mathrm{m}^{3}$, 경기도에서 약 2,540 만 $\mathrm{m}^{3}$ 가 채취되었다(Table 1). 인천광역시의 바다모래의 채취로 신 고채취보다는 허가채취 비율이 높지만 경기도는 허가채 취보다는 신고채취 비율이 5 배 이상 높다.

골재원별로 보면 인천광역시는 산림골재, 바다골재, 선 별파쇄골재, 선별세척골재를 채취하며, 경기도는 산림골 재, 선별파쇄골재, 선별세척골재를 채취하며, 두 지역 모 두 하천골재와 육상골재의 개발은 전혀 없다. 인천광역 시의 골재채취물량 중에는 옹진군에서의 모래채취가 약 600 만 $\mathrm{m}^{3}$ 이며, 나머지는 선별파쇄골재 약 331 만 $\mathrm{m}^{3}$, 산림 골재 약 70 만 $\mathrm{m}^{3}$, 그리고 선별세척골재이다(Table 1). 인 천광역시의 10 개 시군구 중 6 개 시군구에서 골재를 채취

Table 2. The number of aggregate sources in Korea in 2020, by local governments

\begin{tabular}{|c|c|c|c|c|c|c|c|c|c|c|c|c|}
\hline No. of local governments & $\begin{array}{c}\text { Total } \\
\text { Extraction }\end{array}$ & Permission & Declaration & Sand & Gravel & River & Land & Forest & Marine & Crushed & Washing & Others \\
\hline Seoul(25) & 0 & 0 & 0 & 0 & 0 & 0 & 0 & 0 & 0 & 0 & 0 & 0 \\
\hline Incheon $(10)$ & 6 & 2 & 5 & 5 & 6 & 0 & 0 & 1 & 1 & 5 & 2 & 0 \\
\hline Daejeon(5) & 1 & 0 & 1 & 0 & 1 & 0 & 0 & 0 & 0 & 1 & 0 & 0 \\
\hline Gwangju(5) & 0 & 0 & 0 & 0 & 0 & 0 & 0 & 0 & 0 & 0 & 0 & 0 \\
\hline Daegu(8) & 4 & 0 & 4 & 1 & 4 & 0 & 0 & 0 & 0 & 4 & 0 & 0 \\
\hline Busan(16) & 6 & 0 & 6 & 3 & 5 & 0 & 0 & 0 & 0 & 5 & 2 & 0 \\
\hline Ulsan(5) & 3 & 1 & 3 & 2 & 3 & 0 & 0 & 1 & 0 & 3 & 2 & 1 \\
\hline Sejong(1) & 1 & 1 & 1 & 1 & 1 & 0 & 0 & 1 & 0 & 1 & 0 & 0 \\
\hline Gyeonggi-do(31) & 22 & 4 & 21 & 18 & 21 & 0 & 0 & 4 & 0 & 21 & 2 & 0 \\
\hline Gangwon-do(18) & 15 & 11 & 12 & 11 & 15 & 1 & 8 & 6 & 0 & 12 & 0 & 1 \\
\hline Chungcheongnam-do(15) & 14 & 12 & 9 & 12 & 12 & 0 & 5 & 9 & 1 & 8 & 1 & 0 \\
\hline Chungcheongbuk-do(11) & 10 & 6 & 8 & 7 & 9 & 0 & 3 & 6 & 0 & 8 & 0 & 2 \\
\hline Jeollabuk-do(14) & 10 & 8 & 8 & 7 & 9 & 0 & 2 & 8 & 0 & 8 & 0 & 0 \\
\hline Jeollanam-do(22) & 19 & 16 & 10 & 11 & 15 & 0 & 7 & 13 & 0 & 8 & 2 & 2 \\
\hline Gyeongsangbuk-do(23) & 21 & 20 & 12 & 17 & 17 & 2 & 11 & 14 & 0 & 12 & 0 & 0 \\
\hline Gyeongsangnam-do(18) & 18 & 13 & 14 & 12 & 18 & 1 & 1 & 12 & 0 & 14 & 4 & 2 \\
\hline Jeju-do(2) & 2 & 2 & 2 & 2 & 2 & 0 & 2 & 2 & 0 & 2 & 2 & 0 \\
\hline Sum & 152 & 96 & 116 & 109 & 138 & 4 & 39 & 77 & 2 & 112 & 17 & 8 \\
\hline
\end{tabular}


하였다(Table 2). 경기도의 31 개 시군들 중 21개 시군에서 골재를 채취하였다(Table 2). 경기도는 산림골재와 선별 파쇄골재가 주로 이루어졌는데, 산림골재는 약 480 만 $\mathrm{m}^{3}$, 선별파쇄골재는 약 3,335 만 $\mathrm{m}^{3}$ 가 채취되어 선별파쇄골 재의 비율이 압도적으로 높으며, 선별파쇄골재 총생산량 의 약 $49 \%$ 를 점한다. 산림골재는 파주시, 연천군, 포천 시, 가평군의 4 개 시군에서만 이루어졌으며, 21 개 골재채 취 시군 모두에서 선별파쇄골재를 생산하였다. 경기도에 서는 화성시가 가장 많은 골재(약 660 만 $\left.\mathrm{m}^{3}\right)$ 를 생산하였 으며, 그 다음으로 파주시, 포천시, 용인시, 광주시 등으
로 이들 시군 모두 각각 300 만 $\mathrm{m}^{3}$ 이상의 골재를 채취하 였다(Table 3).

강원도 : 2020 년에 강원도에서는 약 1,150 만 $\mathrm{m}^{3}$ 의 골 재를 채취하였으며, 이 중 모래는 약 360 만 $\mathrm{m}^{3}$, 자갈은 약 790 만 $\mathrm{m}^{3}$ 이다. 또한 허가와 신고골재의 비율은 $64: 36$ 으로 허가의 의한 골재생산이 높은 편이다. 산림골재는 약 610 만 $\mathrm{m}^{3}$, 선별파쇄골재는 400 만 $\mathrm{m}^{3}$, 육상골재는 약 32 만 $\mathrm{m}^{3}$ 가 채취되었다(Table 1). 강원도에서 15 개 시군에 서 골재를 채취하였는데, 하천골재는 1 개 군, 육상골재는 8 개 시군, 산림골재는 6 개 시군, 선별파쇄골재는 12 개 시

Table 3. Rank of local governments produced aggregate in Korea, 2020

\begin{tabular}{|c|c|c|c|c|c|c|c|c|c|}
\hline & River & Land & Forest & Marine & Crushed & Washing & Sand & Gravel & $\begin{array}{c}\text { Production of } \\
\text { Aggregate }\end{array}$ \\
\hline 1 & Gumi & $\begin{array}{c}\text { Goseong } \\
\text { (Gangwon) }\end{array}$ & Gimhae & $\begin{array}{c}\text { Ongjin } \\
\text { (Incheon) }\end{array}$ & Hwaseong & Seosan & $\begin{array}{c}\text { Ongjin } \\
\text { (Incheon) }\end{array}$ & Hwaseong & Hwaseong \\
\hline 2 & Hapcheon & Gochang & Wonju & South EEZ & Yongin & $\begin{array}{c}\text { Seo-gu } \\
\text { (Incheon) }\end{array}$ & Cheongju & Paju & $\begin{array}{c}\text { Ongjin } \\
\text { (Incheon) }\end{array}$ \\
\hline 3 & Uiseong & Chungju & Paju & West EEZ & Gwangju & $\begin{array}{l}\text { Saha-gu } \\
\text { (Busan) }\end{array}$ & Pocheon & $\begin{array}{c}\text { Gangseo-gu } \\
\text { (Busan) }\end{array}$ & Paju \\
\hline 4 & Pyeongchang & Hampyeong & Gongju & Taean & Pocheon & Changwon & Yongin & Wonju & Cheongju \\
\hline 5 & & Gangreung & Yeoncheon & & $\begin{array}{l}\text { Gangseo-gu } \\
\text { (Busan) }\end{array}$ & Pyeongtak & Hoengseong & Gwangju & Pocheon \\
\hline 6 & & Yecheon & Cheongju & & Paju & $\begin{array}{l}\text { Nam-gu } \\
\text { (Busan) }\end{array}$ & Yangju & Cheongju & Yongin \\
\hline 7 & & Gumi & Chungju & & Namyangju & Goheung & Gimhae & Pocheon & Gwangju \\
\hline 8 & & Cheonan & Jincheon & & Cheongju & Sacheon & Hwaseong & $\begin{array}{c}\text { Ulju } \\
\text { (Ulsan) }\end{array}$ & Gimhae \\
\hline 9 & & Namwon & Gunsan & & Goyang & $\begin{array}{c}\text { Ulju } \\
\text { (Ulsan) }\end{array}$ & Paju & Gimhae & Wonju \\
\hline 10 & & Sangju & Chuncheon & & Yangju & Jeju & Gongju & Chungju & $\begin{array}{l}\text { Gangseo-gu } \\
\text { (Busan) }\end{array}$ \\
\hline 11 & & Andong & $\begin{array}{c}\text { Ulju } \\
\text { (Ulsan) }\end{array}$ & & Eumseong & Tongyeong & Namyangju & Jincheon & Namyangju \\
\hline 12 & & Gyeongju & Hoengseong & & Yesan & $\begin{array}{c}\text { Nam-gu } \\
\text { (Ulsan) }\end{array}$ & Gwangju & Asan & Jincheon \\
\hline 13 & & Jeju & Naju & & Asan & Geoje & South EEZ & Gunsan & $\begin{array}{c}\text { Ulju } \\
\text { (Ulsan) }\end{array}$ \\
\hline 14 & & Wonju & Hongseong & & $\begin{array}{c}\text { Seo-gu } \\
\text { (Incheon) }\end{array}$ & Gimpo & Yeoju & $\begin{array}{c}\text { Seo-gu } \\
\text { (Incheon) }\end{array}$ & Chungju \\
\hline 15 & & Gimcheon & Hwasun & & Sejong & $\begin{array}{l}\text { Jung-gu } \\
\text { (Incheon) }\end{array}$ & Goseong & Yeoncehon & Yeoncheon \\
\hline 16 & & Cheongju & Sancheong & & Uijeongbu & Seoguipo & Icheon & Namyangju & Goyang \\
\hline 17 & & Yeongju & Seosan & & $\begin{array}{l}\text { Gijang-gun } \\
\text { (Busan) }\end{array}$ & Gwangyang & $\begin{array}{l}\text { Gijang-gun } \\
\text { (Busan) }\end{array}$ & Goyang & Yangju \\
\hline 18 & & Inje & Pocheon & & Gimpo & & Goyang & Naju & Gongju \\
\hline 19 & & Haenam & Jangseong & & Donghae & & Yeoncehon & Yesan & $\begin{array}{c}\text { Seo-gu } \\
\text { (Incheon) }\end{array}$ \\
\hline 20 & & Yesan & Namwon & & Yangsan & & Changwon & Hongseong & Asan \\
\hline
\end{tabular}


군에서 채취되었다(Table 2). 강원도는 타 도에 비해 육 상골재 채취가 활발하며, 육상골재 총 채취량의 약 $32 \%$ 를 점유한다. 강원도에서는 원주시에서의 골재채취가 가 장 많으며, 그 다음으로 춘천시, 횡성군, 동해시 등인데 이들 시군 모두 연 100 만 $\mathrm{m}^{3}$ 이상의 골재를 채취하였다 (Table 3).

충청북도 : 2020 년에 충청북도에서는 약 1,170 만 $\mathrm{m}^{3}$ 의 골재를 채취하였으며, 이 중 모래는 약 400 만 $\mathrm{m}^{3}$, 자갈은 약 770 만 $\mathrm{m}^{3}$ 이다. 또한 허가와 신고골재의 채취비율은 $51: 49$ 이다. 충청북도에서는 하천골재, 바다골재, 선별세 척에 의한 골재채취는 없다. 충청북도에서는 10 개 시군 에서 골재가 채취되었는데, 육상골재는 3 개 시군, 산림골 재는 6 개 시군, 선별파쇄골재는 8 개 시군에서 채취되었 다(Table 2). 산림골재와 선별파쇄골재에서 각각 약 560 만 $\mathrm{m}^{3}$, 육상골재 약 30 만 $\mathrm{m}^{3}$ 가 채취되었다(Table 1). 충 청북도에서는 청주시가 약 420 만 $\mathrm{m}^{3}$ 의 골재를 개발하였 으며, 그 다음으로 진천군, 충주시, 음성군의 순이며, 모 두 100 만 $\mathrm{m}^{3}$ 이상의 골재를 채취하였다(Table 3).

대전, 세종, 충청남도 : 대전광역시는 대덕구에서 선별 파쇄모래만 소량 생산되었으며, 세종특별자치시는 산림 골재와 선별파쇄골재만 채취되었는데, 채취량은 각각 24

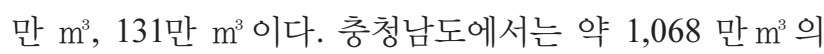
골재가 채취되었으며, 이 중 모래는 약 315 만 $\mathrm{m}^{3}$, 자갈은 753 만 $\mathrm{m}^{3}$ 이다. 또한 허가와 신고골재의 채취비울은 $56: 44$ 로 허가채취가 높은 편이다. 채취량은 산림골재 약 565 만 $\mathrm{m}^{3}$, 선별파쇄골재 약 418 만 $\mathrm{m}^{3}$, 선별세척골재 약 53만 $\mathrm{m}^{3}$, 육상골재 약 22 만 $\mathrm{m}^{3}$ 이다(Table 1). 충청남도에서는 14 개 시군에서 골재를 채취하였는데, 육상골재는 5 개 시 군, 산림골재는 9 개 시군, 바다골재는 1 개 군, 선별파쇄 골재는 8 개 시군, 선별세척골재는 1 개 군에서 채취되었 다(Table 2). 충청남도에서는 공주시가 약 196 만 $\mathrm{m}^{3}$ 의 골 재를 채취하였으며, 그 다음으로 아산시, 예산군, 서산시, 홍성군의 순으로 모두 100 만 $\mathrm{m}^{3}$ 이상의 골재를 채취하였 다(Table 3).

전라북도 : 2020년에 전라북도에서는 약 702 만 $\mathrm{m}^{3}$ 의 골재를 채취하였으며, 이 중 모래는 약 204만 $\mathrm{m}^{3}$, 자갈은 약 498만 $\mathrm{m}^{3}$ 이다. 또한 허가와 신고골재의 채취비율은 $75: 25$ 이다. 전라북도에서는 하천골재, 바다골재, 선별세 척에 의한 골재채취는 없다. 전라북도에서는 10 개 시군 에서 골재를 채취하였으며, 육상골재는 3 개 시군, 산림골 재는 6 개 시군, 선별파쇄골재는 8 개 시군에서 채취되었 다(Table 2). 산림골재는 약 460 만 $\mathrm{m}^{3}$, 선별파쇄골재는 약 175 만 $\mathrm{m}^{3}$, 육상골재 약 68 만 $\mathrm{m}^{3}$ 가 채취되었다(Table 1). 전라북도에서는 군산시와 익산시만 100 만 $\mathrm{m}^{3}$ 이상의 골 재를 채취하였다(Table 3).
광주, 전라남도 : 광주광역시에서는 골재개발이 전혀 없 다. 전라남도에서는 약 871 만 $\mathrm{m}^{3}$ 의 골재를 채취하였으며, 이 중 모래는 약 94 만 $\mathrm{m}^{3}$, 자갈은 약 777 만 $\mathrm{m}^{3}$ 이다. 또 한 허가와 신고골재의 채취비율은 $72: 28$ 이다. 전라남도 에서는 하천골재, 바다골재 채취는 없다. 전라남도에서는 19 개 시군에서 골재를 채취하였는데, 육상골재는 7 개 시 군, 산림골재는 13 개 시군, 선별파쇄골재는 8 개 시군, 선 별세척골재 2개 시군에서 채취되었다(Table 2). 산림골재 는 약 599만 $\mathrm{m}^{3}$, 선별파쇄골재는 약 196만 $\mathrm{m}^{3}$, 육상골재 약 32만 $\mathrm{m}^{3}$, 선별세척골재 약 19 만 $\mathrm{m}^{3}$ 가 채취되었다 (Table 1). 전라남도에서는 나주시와 화순군만 100 만 $\mathrm{m}^{3}$ 이상의 골재를 채취하였다(Table 3).

대구, 경상북도 : 대구광역시에서는 340 만 $\mathrm{m}^{3}$ 의 골재를 채취하였으며, 모두 선별파쇄로 채취되었다. 경상북도에 서는 약 776 만 $\mathrm{m}^{3}$ 의 골재를 채취하였으며, 이 중 모래는 약 257 만 $\mathrm{m}^{3}$, 자갈은 약 519 만 $\mathrm{m}^{3}$ 이다. 또한 허가와 신 고골재의 채취비율은 69:31이다. 경상북도에서는 바다골 재, 선별세척에 의한 골재채취는 없다. 경상북도에서는 21 개 시군에서 골재를 채취하였는데, 하천골재는 2 개 시 군, 육상골재는 11 개 시군, 산림골재는 14 개 시군, 선별 파쇄골재는 12 개 시군에서 채취되었다(Table 2). 산림골 재에서는 약 402 만 $\mathrm{m}^{3}$, 선별파쇄골재는 약 244 만 $\mathrm{m}^{3}$, 육 상골재는 약 94 만 $\mathrm{m}^{3}$, 하천골재는 약 36 만 $\mathrm{m}^{3}$ 가 채취되 었다(Table 1). 경상북도에서는 안동시만 100 만 $\mathrm{m}^{3}$ 이상 의 골재를 채취하였다(Table 3).

부산, 울산, 경상남도 : 부산광역시는 약 552 만 $\mathrm{m}^{3}$ 의 골 재를 채취하였는데 모두 신고골재이다. 모래는 약 144만 $\mathrm{m}^{3}$, 자갈은 약 408 만 $\mathrm{m}^{3}$ 이다. 선별파쇄골재는 5 개 구군, 선별세척골재는 2 개 구에서 채취되었다(Table 2). 울산광 역시는 약 253 만 $\mathrm{m}^{3}$ 의 골재를 채취하였는데, 모래는 18 만 $\mathrm{m}^{3}$, 자갈은 235 만 $\mathrm{m}^{3}$ 이며, 허가와 신고골재의 비율은 $57: 43$ 으로 허가의 채취비율이 높은 편이다. 산림골재는 1 개 군, 선별파쇄골재는 3 개 구군, 선별세척은 2 개 구군에 서 채취되었다(Table 2). 산림골재에서 약 143 만 $\mathrm{m}^{3}$, 선별 파쇄골재에서 약 409 만 $\mathrm{m}^{3}$, 그리고 선별세척골재에서 약 18 만 $\mathrm{m}^{3}$ 가 생산되었다(Table 1). 울주군이 울산광역시에 서는 가장 많은 약 201 만 $\mathrm{m}^{3}$ 의 골재를 채취하였다. 경상 남도는 광역시도들 중 경기도에 이어 두 번째로 많은 1,202 만 $\mathrm{m}^{3}$ 의 골재를 채취하였다. 이 중 모래는 약 342 만 $\mathrm{m}^{3}$, 자갈은 약 859 만 $\mathrm{m}^{3}$ 로 자갈의 채취가 모래보다 약 2.5 배 많다. 또한 허가와 신고골재의 채취비율은 $58: 42$ 이다. 경상남도에서는 바다골재를 제외한 모든 골재를 채 취하였다. 경상남도에서는 18 개 시군에서 골재를 채취하 였는데, 하천골재는 1 개 시군, 육상골재는 1 개 시군, 산 림골재는 12 개 시군, 선별파쇄골재는 14 개 시군에서 채 
취되었다(Table 2). 산림골재에서는 약 688 만 $\mathrm{m}^{3}$, 선별파 쇄골재는 약 363 만 $\mathrm{m}^{3}$, 육상골재는 약 1.5 만 $\mathrm{m}^{3}$, 하천골 재는 약 11 만 $\mathrm{m}^{3}$, 선별세척골재는 약 65 만 $\mathrm{m}^{3}$ 가 채취되 었다(Table 1). 경상남도에서는 김해시와 양산시에서만 100 만 $\mathrm{m}^{3}$ 이상의 골재를 채취하였다(Table 3).

제주특별자치도 : 제주도는 약 148 만 $\mathrm{m}^{3}$ 의 골재를 채 취하였으며, 이 중 모래는 9 만 $\mathrm{m}^{3}$, 자갈은 139 만 $\mathrm{m}^{3}$ 이며, 허가와 신고골재 비율은 61:39로 허가채취 비율이 높다. 제주도는 하천골재와 바다골재의 채취가 없다. 제주도의 2개 시 모두 골재를 채취하고 있으며(Table 2), 두 시 모 두 육상골재, 산림골재, 선별파쇄골재, 선별세척골재를 채 취한다.

\section{6. 시군구별 골재채취 현황}

전국 231 개 시군구 $(229$ 개 시군구 $+\mathrm{EEZ서해,} \mathrm{EEZ남}$ 해)에서 2020년에 골재를 채취한 시군구는 153 개 시군구 $(150$ 개 시군구 $+\mathrm{EEZ}$ 서해, EEZ남해)로 전체 시군구의 약 $66 \%$ 에 달한다. 7 개의 광역시(74개 시군구)에서는 전 년도와 마찬가지로 19 개 군구에서 골재를 채취하였다. 이 들을 제외한 도 지역의 155 개 시군 중 $85 \%$ 인 132 개 시 군에서 골재채취가 이루어졌다. 따라서 광역시를 제외한 국내 대부분의 시군에서 골재를 채취한다고 볼 수 있다. 자갈은 138 개 시군구에서, 모래는 109 개 시군구에서 채 취되었으며, 허가에 의한 골재채취는 96 개 시군구에서, 신고에 의한 골재채취는 116 개 시군구에서 이루어졌다 (Table 2). 권역별로 보면 경기도는 21개 시군, 인천광역 시는 6 개 군구, 강원도는 15 개 시군, 충청북도는 10 개 시 군, 대전, 세종, 충청남도는 각각 1 개, 1 개, 14 개 시군, 전 라북도는 10 개 시군, 전라남도는 19 개 시군, 대구광역시 는 4 개 구군, 경상북도는 21 개 시군, 부산과 울산광역시 는 각각 4 개, 6 개 군구, 경상남도는 18 개 시군, 제주특별 자치도는 2 개 시에서 골재를 채취하였다(Table 2).

골재원별로는 선별파쇄골재를 개발하는 시군구는 112 시군구, 산림골재는 77 개 시군구, 육상골재는 39 개 시군 구, 선별세척은 17 개 시군구, 하천골재는 4 개 시군구, 바 다골재는 2 개 군, 그리고 신고에 의한 산림, 육상과 바다 골재 개발이 8 개 시군구이다(Table 2, Fig. 3). 따라서 우 리나라 시군구에서의 골재개발은 선별파쇄골재가 주도하 고 있으며, 산림골재가 그 뒤를 따르고 있다. 실제로 2020 년의 골재 총 생산의 $87.7 \%$ 가 두 골재원에서 채취되었 다. 선별파쇄골재는 화성시가 가장 많이 생산하였으며 그 다음으로 용인시, 광주시, 포천시, 부산강서구, 파주시, 남 양주시, 청주시, 고양시, 양주시의 순인데 모두 100 만 $\mathrm{m}^{3}$ 이상을 생산하였으며, 대부분 모래보다는 자갈을 더 많
이 생산하며, 부산강서구를 제외하면 모두 수도권에 집 중되어 있는 것이 특징이다(Table 3, Fig. 3(I)). 산림골재 는 김해시에서 가장 많이 채취하였으며, 그 다음으로 원 주시, 파주시, 공주시, 연천군, 청주시, 충주시, 진천군, 군 산시, 춘천시, 울주군의 순인데 선별파쇄골재와 마찬가지 로 채취량이 모두 100 만 $\mathrm{m}^{3}$ 이상이며, 선별파쇄골재 시 군구보다는 좀더 넓은 전국적인 분포를 보인다(Table 3, Fig. $3(\mathrm{H})$ ). 육상골재는 강원도 고성군에서 가장 많이 채 취되었으며, 그 다음으로 고창군, 충주시, 함평군, 강릉시, 예천군, 구미시, 천안시, 남원시, 상주시 등의 순인데 대 부분 평야지대가 넓은 지역을 포함하는 것이 특징이다 (Table 3, Fig. 3(E)), 육상골재는 단기간에 주로 경작지에 서 개발되는 특성으로 인해 많은 양의 골재를 채취하기 는 어렵다. 따라서 육상골재를 가장 많이 채취한 고성군 도 100 만 $\mathrm{m}^{3}$ 이하인 약 87 만 $\mathrm{m}^{3}$ 의 채취량을 보이며, 대 부분 10 만 $\mathrm{m}^{3}$ 내외 이하로 채취되었다. 하천골재는 단지 구미시, 합천군, 의성군, 평창군의 4 개 시군에서만 채취 되었다(Table 3, Fig. 3(D)). 바다골재도 옹진군, 태안군, $\mathrm{EEZ}$ 남해, EEZ서해의 4개 지역에서만 채취되었다. 선별 세척골재는 서산시에서 가장 많이 채취되었으며, 그 다 음으로 인천서구, 부산사하구, 창원시, 평택시, 부산남구, 고흥군, 사천시 등(Table 3, Fig. $3(\mathrm{G})$ )인데 대부분의 선 별세척은 바다에서 채취된 모래를 세척하는 것이므로 대 부분 바다를 끼고 있는 시군들이다.

전국적으로 보았을 때 2020년에 골재를 가장 많이 채 취한 지역은 화성시, 옹진군으로 각각 약 660 만 $\mathrm{m}^{3}, 602$ 만 $\mathrm{m}^{3}$ 를 채취하였는데 화성시는 채취물량은 모두 선별 파쇄골재이며, 옹진군은 약 1 만 $\mathrm{m}^{3}$ 의 선별파쇄를 제외한 물량이 바다골재 채취이다(Table 3). 그 다음으로는 파주 시, 청주시, 포천시, 용인시, 광주시, 김해시 등의 순이며 파주, 청주시는 400 만 $\mathrm{m}^{3}$ 이상, 나머지 4 개 시군은 300 만 $\mathrm{m}^{3}$ 이상을 채취하였으며 200 만 $\mathrm{m}^{3}$ 이상과 100 만 $\mathrm{m}^{3}$ 이 상을 채취한 시군도 각각 8 개 시군, 22 개 시군에 달한다 (Table 3). 따라서 100 만 $\mathrm{m}^{3}$ 이상의 골재를 채취하는 시 군은 전국 229 개 시군구의 $16.6 \%$ 인 38 개 시군구에 불과 하지만 이들의 총 채취물량은 2020 년도 총 채취량의 약 $65 \%$ 를 점유한다. 골재는 모든 시군구에서 반드시 필요한 건설자재이지만 실제 개발은 국내 시군구의 $66 \%$ 인 151 개 시군구에서만 이루어지며, 채취시군구들 중에서도 $25 \%$ 인 38 개 시군구에 전체 골재 채취량의 $65 \%$ 가 집중되고 있어 골재 수급의 불균형을 초래하는 원인이 되기도 한 다. 또한 수도권에 100 만 $\mathrm{m}^{3}$ 이상 골재 생산시군의 $31.5 \%$ 인 12 개 시군구가 집중되어 있다.

골재채취규모와 채취시군을 비교하여 보면 10 만 $\mathrm{m}^{3}$ 이 하의 골재를 채취하는 시군은 21 개 시군구에 채취량은 

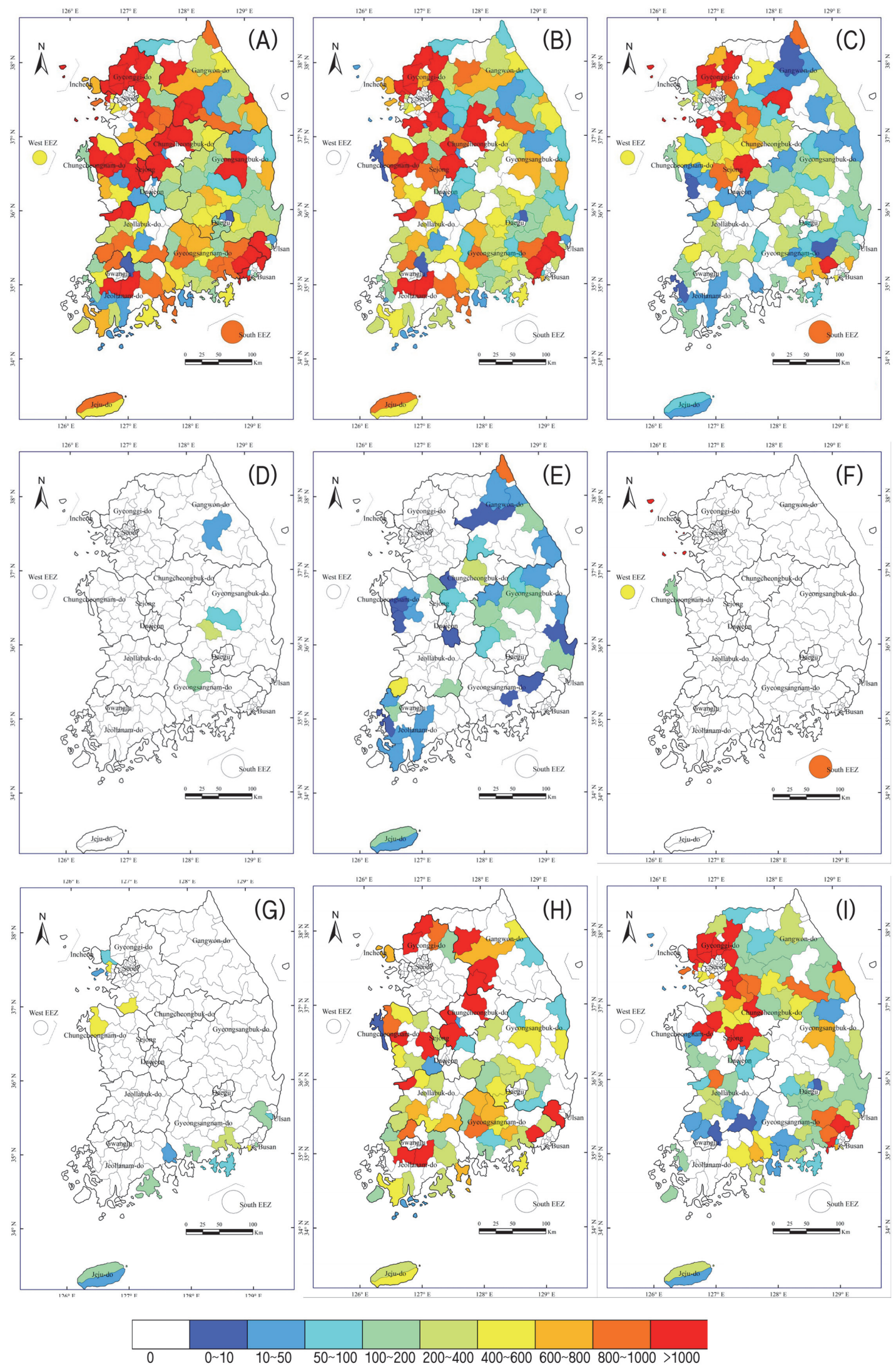

Fig. 3. The distribution map of domestic aggregate by local government. (unit : thousand $\mathrm{m}^{3}$ ) (A) river aggregate, (B) land aggregate, (C) forest aggregate, (D) crushed aggregate, (E) washing aggregate, (F) sand, $(\mathrm{G})$ gravel, $(\mathrm{H})$ total aggregate. 
전체 채취량의 약 $0.6 \%$ 인 약 74 만 $\mathrm{m}^{3}, 10$ 만 $\mathrm{m}^{3} \sim 100$ 만 $\mathrm{m}^{3}$ 의 골재를 채취하는 시군은 94 개 시군구에 채취량은 전 체 채취량의 약 $34 \%$ 인 약 4,493 만 $\mathrm{m}^{3}, 100$ 만 $\mathrm{m}^{3}$ 이상의 골재를 채취하는 시군은 이미 언급한 바와 같이 38 개 시 군구에 채취량은 약 8,574 만 $\mathrm{m}^{3}$ (전체 채취량의 $65 \%$ )이다. 이와 같은 사실은 한 시군구에서의 골재채취는 최소한 10 만 $\mathrm{m}^{3}$ 이상이 되는 것이 적절한 것으로 보인다. 이는 주로 산림골재와 선별파쇄골재에 해당되며, 10 만 $\mathrm{m}^{3}$ 이 하를 채취하는 시군은 주로 하천과 육상골재를 채취한다. 따라서 국내 골재의 채취는 선별파쇄골재와 산림골재 위 주로 개발되면서, 하천, 육상골재는 해당 시군구에서의 자체 수요공급용으로 활용하는 것이 타당할 것으로 생각된다.

\section{7. 골재채취장별 현황}

2020년에는 총 964 개의 채취장이 운영되었는데 이 중 75 개 채취장은 2020 년까지 골재허가기간이 남아있으나 이미 물량을 모두 소진된 곳으로 실제 골재를 채취한 채 취장은 889 개 이다. 이들 중 신고에 의한 골재채취장은 469 개소, 허가에 의한 골재채취장은 420 개소이다(Table 4,

Fig. 4). 또한 모래만 채취한 채취장은 373 개소, 자갈만
채취한 채취장은 401개소, 그리고 모래와 자갈 모두 채 취하는 채취장은 115 개소이다. 골재원별로 보면 선별파 쇄장이 415 개소로 가장 많으며, 그 다음으로 산림골재장 196 개소, 육상골재장 167 개소, 바다골재장 47 개소, 선별 세척장 44 개소, 하천골재장 10 개소이며, 나머지 바다신 고, 산림골재신고, 육상골재신고가 10개소이다(Table 4). 광역시도별로 보면 100 개소 이상의 골재채취장이 있는 지역은 3 개도로 경기도는 135 개소, 경상북도는 125 개소, 강원도는 110 개소이며, 경상남도(94개소), 충청북도 87 개 소, 충청남도(62개소), 전라북도(61개소), 전라남도(60개 소) 등에서는 각 도내에 50 개소 이상의 채취장이 운영되 고 있다. 그리고 인천광역시, 제주도, 울산광역시, 부산광 역시, 남해 및 서해 EEZ은 10 개 이상의 채취장을, 대구 광역시, 세종시, 대전광역시 등은 10 개 이하의 채취장이 운영되고 있다(Table 4).

부산광역시, 대구광역시, 대전광역시는 신고에 의한 골 재채취장만 운영되고 있으며, 강원도, 경상북도, 전라남 도, 전라북도, 충청북도는 허가에 의한 골재장이 더 많으 며, 다른 시도는 신고에 의한 골재채취장이 더 우세한 편 이다. 전국 시군구에서 채취장이 가장 많은 시군구는 청 주시로 27 개소이며, 그 다음으로 고성군, 강릉시, 제주시,

Table 4. The active operations by aggregate source and by provinces in Korea, 2020

\begin{tabular}{|c|c|c|c|c|c|c|c|c|c|c|}
\hline \multirow[b]{2}{*}{ Province } & \multicolumn{4}{|c|}{ permission } & \multicolumn{5}{|c|}{ declaration } & \multirow{2}{*}{ Total } \\
\hline & River & Land & Forest & Marine & Land & Forest & Marine & Crushed & Washing & \\
\hline \multicolumn{11}{|l|}{ Seoul } \\
\hline Incheon & & & 1 & 15 & & & & 12 & 7 & 35 \\
\hline Gyeonggi-do & & & 8 & & & & & 125 & 2 & 135 \\
\hline Gangwon-do & 7 & 53 & 14 & & & 1 & & 35 & & 110 \\
\hline Chungcheongbuk-do & & 15 & 21 & & 1 & 1 & & 49 & & 87 \\
\hline Daejeon & & & & & & & & 1 & & 1 \\
\hline Sejong & & & 1 & & & & & 8 & & 9 \\
\hline Chungcheongnam-do & & 7 & 21 & 3 & & & & 30 & 1 & 62 \\
\hline Jeollabuk-do & & 15 & 24 & & & & & 22 & & 61 \\
\hline \multicolumn{11}{|l|}{ Gwangju } \\
\hline Jeollanam-do & & 12 & 27 & & & 1 & 1 & 15 & 4 & 60 \\
\hline Daegu & & & & & & & & 9 & & 9 \\
\hline Gyeongsangbuk-do & 2 & 58 & 32 & & & & & 33 & & 125 \\
\hline Busan & & & & & & & & 16 & 3 & 19 \\
\hline Ulsan & & & 6 & & & 2 & 1 & 9 & 2 & 20 \\
\hline Gyeongsangnam-do & 1 & 2 & 31 & & & & 2 & 43 & 15 & 94 \\
\hline Jeju-do & & 5 & 10 & & & & & 8 & 10 & 33 \\
\hline EEZ of South Sea & & & & 13 & & & & & & 13 \\
\hline EEZ of West Sea & & & & 16 & & & & & & 16 \\
\hline Total & 10 & 167 & 196 & 47 & 1 & 5 & 4 & 415 & 44 & 889 \\
\hline
\end{tabular}




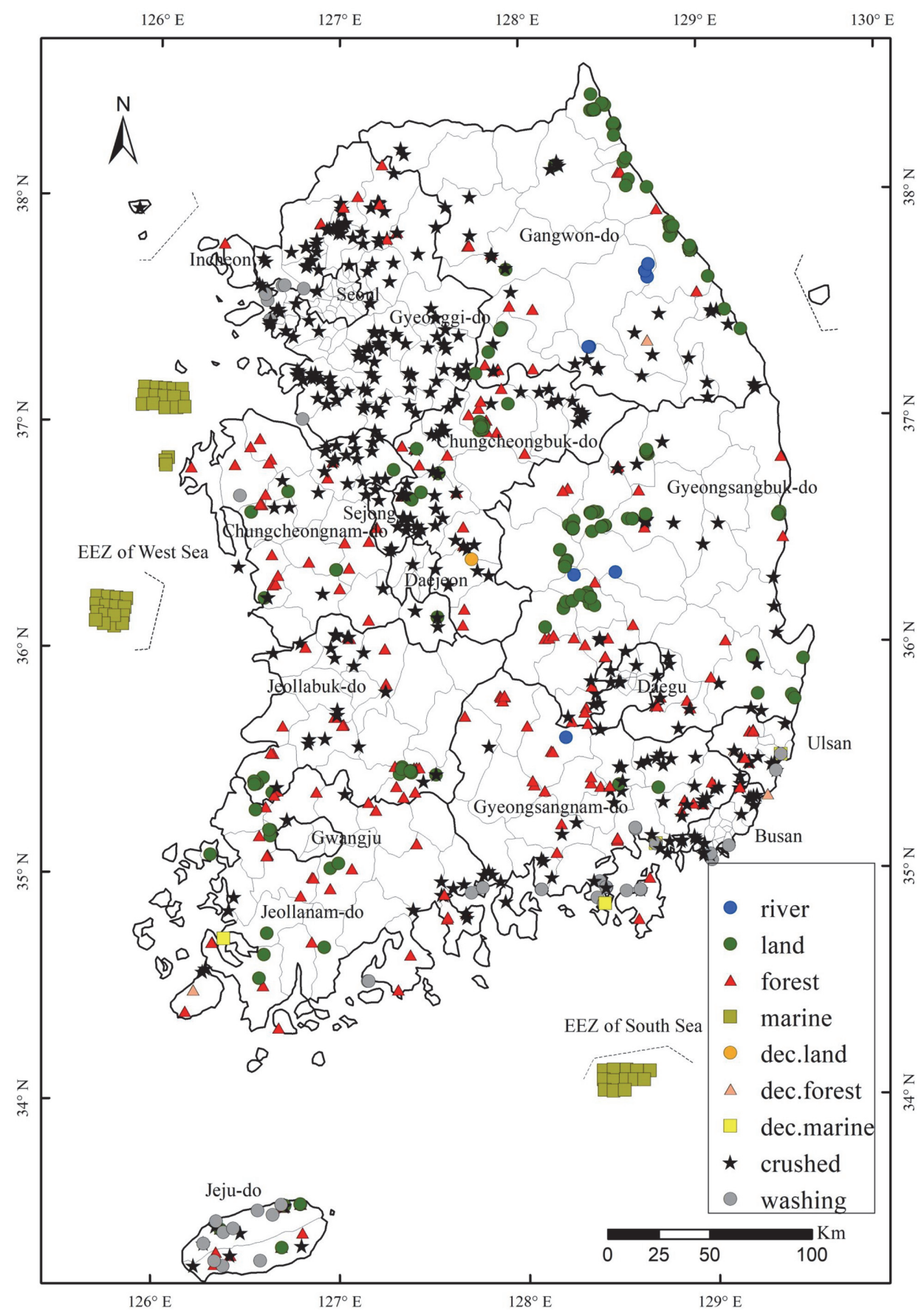

Fig. 4. The distribution map of the active operations of aggregates in Korea, 2020.

화성시 등으로 20 개소 이상의 채취장이 운영되었다. 남 원시, 충주시, 서해EEZ, 옹진군, 울주군, 안동시 등은 10 개 이상의 채취장을 운영하였는데 10 개소 이상, 20 개소 미만의 채취장을 운영한 시군구는 22개이다. 나머지 123 개 시군구에서는 10 개소 미만의 채취장을 운영하였다.

채취장들 중에서 골재의 채취가 가장 많은 부산강서구 의 채취장으로 약 163 만 $\mathrm{m}^{3}$ 의 골재를 채취하였다. 100 만 $\mathrm{m}^{3}$ 이상을 채취한 채취장은 14 개소이다(Table 5). 50
만 100 만 $\mathrm{m}^{3}$ 의 골재를 채취한 채취장은 50 개소로 총 채 취물량은 약 3,353 만 $\mathrm{m}^{3}, 10$ 만 50 만 $\mathrm{m}^{3}$ 규모의 채취장은 288 개소로 총물량은 약 6,264 만 $\mathrm{m}^{3}, 1$ 만 10 만 $\mathrm{m}^{3}$ 규모의 채취장은 411 개소이며 채취물량은 약 1,761 만 $\mathrm{m}^{3}, 1$ 만 $\mathrm{m}^{3}$ 이하의 소규모 채취장도 126 개소로 채취물량은 약 70 만 $\mathrm{m}^{3}$ 으로 한 채취장당 평균 약 15 만 $\mathrm{m}^{3}$ 의 골재를 채취하였다.

196 개소의 산림골재 채취장 중에서 가장 많은 채취량 을 보이는 채취장은 군산시의 채취장으로 약 145 만 $\mathrm{m}^{3}$ 
Table 5. Aggregate production in Korea in 2020, by aggregate source and size of operation

\begin{tabular}{|c|c|c|c|c|c|c|c|c|c|c|c|c|}
\hline \multirow{2}{*}{$\begin{array}{c}\text { size range } \\
\text { (thousand } \mathrm{m}^{3} \text { ) }\end{array}$} & \multicolumn{2}{|c|}{ river } & \multicolumn{2}{|c|}{ Land } & \multicolumn{2}{|c|}{ Forest } & \multicolumn{2}{|c|}{ Marine } & \multicolumn{2}{|c|}{ Crushed } & \multicolumn{2}{|c|}{ Washing } \\
\hline & $\begin{array}{l}\text { number of } \\
\text { operations }\end{array}$ & quantities & $\begin{array}{c}\text { number of } \\
\text { operations }\end{array}$ & quantities & $\begin{array}{l}\text { number of } \\
\text { operations }\end{array}$ & quantities & $\begin{array}{c}\text { number of } \\
\text { operations }\end{array}$ & quantities & $\begin{array}{l}\text { number of } \\
\text { operations }\end{array}$ & quantities & $\begin{array}{l}\text { number of } \\
\text { operations }\end{array}$ & quantities \\
\hline$\leq 10$ & 7 & 31.0 & 60 & 356.8 & 7 & 26.7 & 3 & 21.1 & 38 & 190.8 & 10 & 65.9 \\
\hline $10 \sim \leq 20$ & 0 & 0.0 & 50 & 793.8 & 7 & 106.4 & 6 & 86.4 & 31 & 489.1 & 7 & 106.1 \\
\hline $20 \sim \leq 40$ & 0 & 0.0 & 33 & 905.9 & 21 & 622.2 & 10 & 281.3 & 51 & $1,467.7$ & 8 & 212.4 \\
\hline $40 \sim \leq 60$ & 0 & 0.0 & 9 & 428.3 & 8 & 437.6 & 6 & 313.9 & 44 & $2,199.1$ & 4 & 182.5 \\
\hline $60 \sim \leq 80$ & 1 & 68.0 & 6 & 424.0 & 17 & $1,209.5$ & 5 & 372.4 & 34 & $2,428.7$ & 2 & 123.4 \\
\hline $80 \sim \leq 100$ & 0 & 0.0 & 5 & 443.0 & 14 & $1,261.2$ & 1 & 82.8 & 25 & $2,230.9$ & 2 & 166.0 \\
\hline $100 \sim \leq 200$ & 1 & 111.0 & 4 & 504.3 & 51 & $7,318.2$ & 5 & 846.1 & 91 & $13,465.0$ & 5 & 639.7 \\
\hline $200 \sim \leq 300$ & 1 & 288.0 & 0 & 0.0 & 24 & $5,872.4$ & 2 & 485.0 & 39 & $9,864.3$ & 4 & 928.8 \\
\hline $300 \sim \leq 400$ & 0 & 0.0 & 0 & 0.0 & 12 & $4,143.0$ & 3 & $1,081.0$ & 21 & 7,359.9 & 0 & 0.0 \\
\hline $400 \sim \leq 500$ & 0 & 0.0 & 0 & 0.0 & 6 & $2,655.1$ & 1 & 411.0 & 12 & $5,406.8$ & 1 & 421.9 \\
\hline $500 \sim \leq 600$ & 0 & 0.0 & 0 & 0.0 & 6 & $3,198.7$ & 2 & $1,026.0$ & 11 & $6,043.7$ & 1 & 528.0 \\
\hline $600 \sim \leq 700$ & 0 & 0.0 & 0 & 0.0 & 6 & $3,944.1$ & 0 & 0.0 & 5 & $3,151.7$ & 0 & 0.0 \\
\hline $700 \sim \leq 800$ & 0 & 0.0 & 0 & 0.0 & 4 & $3,061.0$ & 2 & $1,486.0$ & 4 & 2,993.4 & 0 & 0.0 \\
\hline $800 \sim \leq 900$ & 0 & 0.0 & 0 & 0.0 & 5 & $4,296.0$ & 0 & 0.0 & 0 & 0.0 & 0 & 0.0 \\
\hline $900 \sim \leq 1,000$ & 0 & 0.0 & 0 & 0.0 & 3 & $2,879.5$ & 1 & 919.0 & 0 & 0.0 & 0 & 0.0 \\
\hline $1,000 \sim \leq 1,500$ & 0 & 0.0 & 0 & 0.0 & 5 & $5,895.2$ & 0 & 0.0 & 7 & 7,777.6 & 0 & 0.0 \\
\hline $1,500 \sim \leq 2,000$ & 0 & 0.0 & 0 & 0.0 & 0 & 0.0 & 0 & 0.0 & 2 & $3,197.4$ & 0 & 0.0 \\
\hline$>2,000$ & 0 & 0.0 & 0 & 0.0 & 0 & 0.0 & 0 & 0.0 & 0 & 0.0 & 0 & 0.0 \\
\hline total & 10 & 498.0 & 167 & $3,856.1$ & 196 & $46,926.8$ & 47 & $7,412.0$ & 415 & $68,266.1$ & 44 & $3,374.7$ \\
\hline
\end{tabular}

Table 5. Continued

\begin{tabular}{|c|c|c|c|c|c|c|}
\hline \multirow{2}{*}{$\begin{array}{c}\text { size range } \\
\text { (thousand } \mathrm{m}^{3} \text { ) }\end{array}$} & \multicolumn{2}{|c|}{ sand } & \multicolumn{2}{|c|}{ gravel } & \multicolumn{2}{|c|}{ Aggregate } \\
\hline & $\begin{array}{l}\text { number of } \\
\text { operations }\end{array}$ & quantities & $\begin{array}{l}\text { number of } \\
\text { operations }\end{array}$ & quantities & $\begin{array}{c}\text { number of } \\
\text { operations }\end{array}$ & quantities \\
\hline$\leq 10$ & 101 & 582.0 & 47 & 219.8 & 126 & 700.3 \\
\hline $10 \sim \leq 20$ & 78 & $1,232.0$ & 38 & 569.9 & 101 & $1,581.8$ \\
\hline $20 \sim \leq 40$ & 76 & $2,076.6$ & 63 & $1,915.0$ & 125 & $3,548.6$ \\
\hline $40 \sim \leq 60$ & 46 & $2,307.9$ & 41 & $2,115.7$ & 73 & $3,669.0$ \\
\hline $60 \sim \leq 80$ & 32 & $2,248.6$ & 49 & $3,512.4$ & 65 & $4,626.0$ \\
\hline $80 \sim \leq 100$ & 27 & $2,394.9$ & 23 & $2,086.5$ & 47 & $4,183.9$ \\
\hline $100 \sim \leq 200$ & 63 & $9,035.6$ & 112 & $16,130.4$ & 160 & $23,189.3$ \\
\hline $200 \sim \leq 300$ & 32 & $7,996.8$ & 61 & $14,967.0$ & 71 & $17,655.1$ \\
\hline $300 \sim \leq 400$ & 12 & $4,138.2$ & 38 & $13,203.0$ & 37 & $12,900.9$ \\
\hline $400 \sim \leq 500$ & 5 & $2,179.9$ & 13 & $5,599.6$ & 20 & $8,894.8$ \\
\hline $500 \sim \leq 600$ & 8 & $4,263.2$ & 7 & $3,860.7$ & 20 & $10,796.4$ \\
\hline $600 \sim \leq 700$ & 0 & 0.0 & 9 & $5,938.0$ & 11 & $7,095.8$ \\
\hline $700 \sim \leq 800$ & 3 & $2,281.0$ & 5 & $3,820.8$ & 10 & $7,540.4$ \\
\hline $800 \sim \leq 900$ & 1 & 865.8 & 4 & $3,426.2$ & 5 & $4,296.0$ \\
\hline $900 \sim \leq 1,000$ & 1 & 919.0 & 2 & $1,919.9$ & 4 & $3,798.5$ \\
\hline $1,000 \sim \leq 1,500$ & 1 & $1,229.2$ & 6 & $6,682.4$ & 12 & $13,672.8$ \\
\hline $1,500 \sim \leq 2,000$ & 0 & 0.0 & 1 & $1,629.0$ & 2 & $3,197.4$ \\
\hline$>2,000$ & 0 & 0.0 & 0 & 0.0 & 0 & 0.0 \\
\hline total & 486 & $43,750.7$ & 519 & $87,596.3$ & 889 & $131,347.0$ \\
\hline
\end{tabular}


를 채취하였다. 100 만 $\mathrm{m}^{3}$ 이상을 채취한 산림골재 채취 장은 5 개소이며, 50 만 100 만 $\mathrm{m}^{3}$ 를 채취하는 채취장은 29 개소, 10 만 50 만 $\mathrm{m}^{3}$ 를 채취하는 채취장은 93 개소, 1 만 $\sim 10$ 만 $\mathrm{m}^{3}$ 를 채취하는 채취장은 67 개소, 1 만 $\mathrm{m}^{3}$ 이하의 채취장은 7 개소로 국내 산림골재 채취장은 50 만 $\mathrm{m}^{3}$ 이하 를 채취하는 채취장이 우세하게 많은 것을 알 수 있다 (Table 5). 산림골재 채취장당 평균 채취량은 약 24 만 $\mathrm{m}^{3}$ 이다. 2020년에 선별파쇄장은 약 415 개소가 운영되었으며, 가 장 많은 채취한 곳은 부산 강서구에 위치한 채취장으로 약 163 만 $\mathrm{m}^{3}$ 를 채취하였다. 100 만 $\mathrm{m}^{3}$ 이상을 채취한 선 별파쇄장은 9 개소이며, 50 만 100 만 $\mathrm{m}^{3}$ 를 채취하는 채취 장은 20 개소, 10 만 50 만 $\mathrm{m}^{3}$ 를 채취하는 채취장은 163 개 소, 1 만 10 만 $\mathrm{m}^{3}$ 를 채취하는 채취장은 185 개소, 1 만 $\mathrm{m}^{3}$ 이하의 채취장은 38 개소로 국내 선별파쇄 채취장은 산림 골재와 마찬가지로 50 만 $\mathrm{m}^{3}$ 이하를 채취하는 채취장이 우세하게 많은 것을 알 수 있다(Table 5). 선별파쇄 채취 장당 평균 채취량은 약 16 만 $\mathrm{m}^{3}$ 이다.

육상골재 채취장은 약 167 개소가 운영되었는데 가장 채취물량이 많는 곳은 고창군에 위치한 채취장으로 약 14 만 $\mathrm{m}^{3}$ 를 채취하였다. 육상골재의 채취여건상 채취물량 은 산림, 선별파쇄골재보다 적어 대부분 10 만 $\mathrm{m}^{3}$ 이하의 물량을 채취한다. 10 만 $\mathrm{m}^{3}$ 이상을 채취하는 채취장은 4 개소, 1 만 10 만 $\mathrm{m}^{3}$ 를 채취하는 채취장은 103 개소, 1 만 $\mathrm{m}^{3}$ 이하의 채취장은 60 개소인데 대부분 2 만 $\mathrm{m}^{3}$ 이하의 채취장이 110 개소로 압도적으로 많다(Table 5). 육상골재 채취장당 평균 채취량은 약 2 만 $\mathrm{m}^{3}$ 이다.

선별세척 채취장은 약 44 개소가 운영되었는데 가장 채 취량이 많은 곳은 서산시의 채취장으로 약 53 만 $\mathrm{m}^{3}$ 를 채 취하였다. 선별세척 채취장도 규모는 그다지 크지 않아 10 만 50 만 $\mathrm{m}^{3}$ 를 채취하는 채취장은 10 개소, 1 만 10 만 $\mathrm{m}^{3}$
를 채취하는 채취장은 26 개소, 1 만 $\mathrm{m}^{3}$ 이하의 채취장은 10 개소이다(Table 5). 선별세척 채취장당 평균 채취량은 약 8 만 $\mathrm{m}^{3}$ 이다.

바다골재 채취장은 약 47 개소가 운영되었는데 가장 채 취량이 많은 곳은 옹진군의 채취장으로 약 92 만 $\mathrm{m}^{3}$ 를 채 취하였다. 바다골재는 채취구역을 미리 설정하고 그 구 역 내에서 여러 채취업체들이 채취하는 방식을 취하고 있어 실제 채취장은 옹진군, 서해 및 남해 $\mathrm{EEZ}$, 그리고 태안군의 4 개 지역이다. 50 만 $\mathrm{m}^{3}$ 이상을 채취하는 채취 장은 5 개소, 10 만 50 만 $\mathrm{m}^{3}$ 를 채취하는 채취장은 11 개소, 1 만 10 만 $\mathrm{m}^{3}$ 를 채취하는 채취장은 28 개소, 1 만 $\mathrm{m}^{3}$ 이하 의 채취장은 3 개소이다(Table 5). 바다골재 채취장당 평 균 채취량은 약 16 만 $\mathrm{m}^{3}$ 이다.

골재채취에는 허가에 의한 골재채취와 신고에 의한 골재 채취 등 두 가지 방법이 있다. 허가는 국유지 또는 사유지 에 골재개발을 목적으로 사업을 하고자 하는 경우 필요한 절차이며, 신고는 골재개발이 목적은 아니고 도로, 주택, 산업단지 등의 여러 개발행위를 하는데 있어 불가피하게 암반을 제거해야 하는 경우가 있는데 이렇게 제거된 암반 을 골재로 활용하기 위한 절차이다(Hong and Lee, 2021). 따라서 신고골재 업체는 직접 골재를 개발하지 않으며, 다른 지역에서 개발행위로 인해 나온 암석들을 구매하여 파쇄를 하는 것이다. 허가와 신고는 모두 골재를 생산하고 자 기간이 명시되어 있었는데 골재채취법 개정을 통해 신고는 직접 골재를 개발하는 행위가 없으므로 신고기간의 규제를 폐지하였다(Hong and Lee, 2021). 따라서 현재는 허가에 의한 골재개발에서만 허가기간의 규제가 남아있다.

Table 6에 2020년에 가행된 채취장들의 허가기간과 2021년 이후에도 남아있는 허가기간을 제시하였다. 2020 년에 허가기간이 유지되고 있는 골재채취장은 420 개소인

Table 6. The number of operation of aggregate by permitted period, and remaining period from 2021

\begin{tabular}{|c|c|c|c|c|c|c|c|c|c|c|}
\hline \multirow[b]{2}{*}{ year } & \multicolumn{5}{|c|}{ permitted period } & \multicolumn{5}{|c|}{ remaining period from 2021} \\
\hline & river & land & forest & marine & sum & river & land & forest & marine & sum \\
\hline$\leq 1$ & 8 & 63 & 4 & 16 & 91 & & 69 & 36 & 3 & 108 \\
\hline $1 \sim \leq 2$ & & 64 & 4 & & 69 & & 16 & 40 & 15 & 71 \\
\hline $2 \sim \leq 4$ & 1 & 28 & 15 & 15 & 58 & & 5 & 41 & & 46 \\
\hline $4 \sim \leq 6$ & & 10 & 22 & 16 & 47 & & & 36 & 16 & 52 \\
\hline $6 \sim \leq 8$ & & 2 & 19 & & 22 & & & 13 & & 13 \\
\hline $8 \sim \leq 10$ & 1 & & 63 & & 64 & & & 5 & & 6 \\
\hline $10 \sim \leq 15$ & & & 30 & & 30 & & & & & \\
\hline $15 \sim \leq 20$ & & & 27 & & 27 & & & & & \\
\hline $20 \sim \leq 25$ & & & 8 & & 8 & & & & & \\
\hline $25 \sim \leq 30$ & & & 3 & & 3 & & & & & \\
\hline$>30$ & & & 1 & & 1 & & & & & \\
\hline & 10 & $' 167$ & 196 & 47 & 420 & & 90 & 171 & 34 & 296 \\
\hline
\end{tabular}


데, 산림골재 197 개소, 육상골재 167 개소, 바다골재 47 개 소, 하천골재 10 개소이다. 허가기간은 최장 약 32 년에서 최소 약 2 개월의 분포범위를 보인다. 허가기간이 25 년 이 상은 4 개 채취장, 20 년 25 년은 8 개 채취장, 15 년 20 년은 27 개 채취장, 10 년 15 년은 30 개 채취장, 6 년 10 년은 86 개 채취장, 2 년 6년은 105 개 채취장, 1 년 2년은 69 개 채 취장, 나머지 91 개 채취장은 1년 이하의 허가기간을 보 인다. 5 년 이상의 비교적 장기적인 허가기간을 보유한 채 취장은 극히 일부를 제외하고는 모두 산림골재 채취장이 며, 대부분의 육상골재는 1 년 2년의 짧은 허가기간을 갖 는 것이 특징이다. 2020 년에 채취가 종료되는 채취장은 124 개소로 2021 년 이후 채취가 가능한 채취장은 296개 소이며, 2021년에 채취가 종료되는 채취장은 108 개소이 다. 2021년 이후에도 지속적으로 개발이 가능한 채취장 은 약 108 개소이다. 골재원별로 보면 2021년 이후(2022 년)에도 개발이 가능한 산림골재 채취장은 136 개소, 육 상골재 22 개소, 하천골재는 없으며, 바다골재는 34 개소 이다. 따라서 지속적이고 원활한 골재공급이 이루어지기 위해서는 허가골재 부문에서 최소한 100 개소 이상의 채 취장이 연장허가되거나 신규허가를 받아야 정상적인 공 급이 이루어질 수 있을 것이다.

\section{7. 결 론}

1. 2020 년도에는 약 1 억 3,135 만 $\mathrm{m}^{3}$ 의 골재를 채취하였 으며, 이 중 선별파쇄골재가 가장 많은 6,827 만 $\mathrm{m}^{3}$ 를 채 취하고, 산림골재 4,682만 $\mathrm{m}^{3}$, 바다골재 741 만 $\mathrm{m}^{3}$, 육상 골재 386 만 $\mathrm{m}^{3}$, 선별세척골재 337 만 $\mathrm{m}^{3}$ 기타 112 만 $\mathrm{m}^{3}$ 를 채취하였다. 또한 모래는 4,386 만 $\mathrm{m}^{3}$, 자갈은 8,749 만 $\mathrm{m}^{3}$ 가 채취되었으며, 허가에 의해서는 5,858 만 $\mathrm{m}^{3}$, 비허가 신 고에 의해서는 7,277 만 $\mathrm{m}^{3}$ 가 채취되었다.

2. 2020 년도에는 17 개 광역시도 중 15 개 광역시도에서 골재를 채취하였으며, 경기도가 골재채취량의 $29 \%$ 인 3,868 만 $\mathrm{m}^{3}$ 의 골재를 채취하였으며, 경상남도, 충청북도, 강원 도, 충청남도, 인천광역시는 1,000 만 $\mathrm{m}^{3}$ 이상의 골재를 채 취하였다. 특히, 경기도는 선별파쇄골재의 채취량의 전국 선별파쇄골재 물량의 $49 \%$ 로 압도적으로 많은 채취량을 보이는 것이 특징이다.

3. 2020 년도에는 231 개 시군구의 약 6 인 153 개 시군구 에서 골재를 채취하였으며, 선별파쇄가 주 생산원인 화 성시와 바다모래가 주 생산원인 옹진군이 600 만 $\mathrm{m}^{3}$ 이상 의 골재를 채취하였다. 이들을 포함하여 총 38 개 시군구 에서 100 만 $\mathrm{m}^{3}$ 이상의 골재를 채취하였으며, 채취량은 전 국 채취량의 $65 \%$ 인 약 8,567 만 $\mathrm{m}^{3}$ 이다. 나머지 115 개 시 군구가 전국 채취량의 $35 \%$ 를 담당하고 있다.
4. 2020 년도에는 약 1,040 여개소의 채취장이 운영되었 으나 실제 골재를 채취한 채취장은 약 889 개 채취장이다. 미채취장은 당해연도에 채취를 하지 않았거나 허가물량을 소진하여 채취를 하지 않은 곳이다. 선별파쇄장이 약 415 개소로 가장 많으며, 산림골재, 육상골재장은 100 개소 이 상에서 개발되었다. 100 개소 이상의 채취장이 있는 지역 은 경기도, 경상북도, 강원도이다. 시구구별로 보면 청주 시, 강원고성군, 강릉시, 제주시 등에 20 개소 이상의 채 취장 위치한다. 100 만 $\mathrm{m}^{3}$ 이상을 채취한 채취장은 14 개 채취장이며, 1 만 $\mathrm{m}^{3}$ 이하의 소규모 채취장도 약 126 개소이다.

5. 약 420 여개의 허가채취장에서 허가기간은 최장 32 년에서 최소 2 개월이며, 5 년 이상의 허가기간을 갖는 채 취장은 189 개소이며, 1 년 이하의 단기 운영 채취장도 91 개소이다. 허가 잔여기간을 보면 2020년도에 허가 만료 인 채취장은 124 개소, 2021년에 허가 만료인 채취장은 108 개소이다. 이는 2021년 이후 채취가능한 채취장이 약 $55 \%$ 이며, 2020년 수준의 허가 골재채취물량을 유지하 기 위해서는 최소한 200 여개 이상의 채취장에 대해 허가 연장, 신규허가가 필요할 것이다.

\section{사 사}

이 연구는 한국지질자원연구원에서 수행하고 있는 국 토교통부 "2021년 골재자원조사 및 관리사업(IP2021-006)" 의 지원으로 수행되었습니다. 또한 논문에 대한 세심한 검토와 제안을 해주신 심사위원 분들게 감사드립니다.

\section{References}

Hong, S.S., Kim, J.Y. and Lee, J.Y. (2015) Trends of supply and demand of aggregate in Korea(I). Jour.Petro.Soc.Korea, v.24, p.253-272. doi: 10.7854/JPSK.2015.24.3.253

Hong, S.S. and Lee, J.Y. (2020) Analysis of 2019 domestic aggregate production in Korea(I). Korea Econ. Environ. Geol., v.53, p.755-769. doi: 10.9719/EEG.2020.53.6.755

Hong, S.S. and Lee, J.Y. (2021) Analysis of 2019 domestic aggregate production in Korea(II). Korea Econ. Environ. Geol., v.54, p.427-439. doi: 10.9719/EEG.2021.54.4.427

Ministry of Land, Infrastructure and Transport, 2019, Annual aggregate statistics, www.agris.go.kr

Ministry of Land, Infrastructure and Transport, 2014, The $5^{\text {th }}$ Basic plan for supply and demand of aggregate, 358p.

Ministry of Land, Infrastructure and Transport, 2018, The $6^{\text {th }}$ Basic plan for supply and demand of aggregate, 368p.

Willett, J.C. (2020) Sand and gravel, construction(advance release), 2017 Minerals Yearbook, U.S. Geological Survey, 14p.

Willett, J.C. (2020) Stone, crushed(advance release), 2017 Minerals Yearbook, U.S. Geological Survey, 26p. 